Vilain. Rude, maussade, chiche, meschant, sordide, maupiteus, casanier, ord ou ordelot, deshonneste, mal-gratieus, laid ou enlaidi, infame, odieus, desplaisant, facheus, avare, miserable, desdaigneus, superbe, ingrat, terre-né.

Vileté, Vilité ou Vieuté. Contemptible, lasche, sordide, basse, inutile, mesprisée, vulgaire, infructueuse, abjecte, humble. ${ }^{1}$

\title{
Vile Birds and Beasts in Jean Lemaire de Belges's Epîtres de l'Amant Vert
}

\section{Emma Herdman}

\begin{abstract}
This article studies the various physical, social and moral criteria that determine villainy - in the various senses implied by Maurice de la Porte's Epithetes (1571) - in Renaissance birds. It focuses primarily on Jean Lemaire de Belges's Epîtres de l'Amant Vert (1505-11), two poems whose praise of Lemaire's patron, Marguerite d'Autriche, is couched in praise of (and by) her pet parrot, the Amant Vert. For all that the poems show the Amant Vert's distinctions between the vile and the noble to be confirmed in the afterlife, his seriocomic perception of himself as tragically noble risks destabilising his narrative judgment: he is, after all, a parrot. The article therefore considers the ambiguity of the Amant Vert and the contrasting stability of his conceptions of the vile, comparing his criteria for determining villainy with those found in less paradoxical forms of writing. This study of villainy in Renaissance birds thereby tests how valuable a contribution such ambiguous or unstable genres as the serio-comic or the paradoxical may make to the study of shifting and versatile concepts such as the vile.
\end{abstract}

Keywords: vile; birds; Renaissance; Jean Lemaire de Belges; Epîtres de l'Amant Vert; seriocomic writing; paradoxical encomia

As the suicidal parrot narrator of Jean Lemaire de Belges's Epîtres de l'Amant Vert (1505-1511) makes the final preparations for his death, he addresses the dog whose jaws will shortly end his life:

Attens ung peu, vilaine creature,

\footnotetext{
${ }^{1}$ Maurice de La Porte, Les Epithetes (1571), ed. by François Rouget (Paris: Champion, 2009), p. 592.
} 
Tu jouÿras d'une noble pasture. ${ }^{2}$

The contrast in this couplet between 'vilaine' and 'noble' neatly encapsulates the paradox at the heart of these two poems. It highlights both the noble parrot's worth and, thereby, the tragedy of his fate: the first of his two letters to his royal mistress, Marguerite d'Autriche, describes how fear of having lost her favour has driven her loyal parrot to suicide. Equally, through the vile dog it establishes the converse associations between villainy and eating, and between villainy and death. These associations will be developed in the second letter, written from beyond the grave, in which the Amant Vert recounts his descent to the Underworld: his distinction between the noble and the vile will be confirmed in the afterlife, as the dog is condemned but the parrot taken to paradise. However, the paradox of the poems derives not from this contrast but from the comic juxtaposition 'noble pasture': pathos turns to bathos as the Amant Vert's nobly tragic status is undermined by this belittling description of his body at his death. Lemaire's parrot narrator thus occupies an ambiguous position as a tragic but lowly protagonist whose plight is more comical than pitiful, and as a mimic that grandly imitates humans but nevertheless remains a bird: this ambiguity permeates the text, lending the poems a serio-comic tone that prevents the Amant Vert from being taken entirely seriously. ${ }^{3}$

This serio-comic tone is, of course, entirely appropriate to the genre of paradoxical encomium, which remains fully aware of the comic disproportion with which it inflates its unconventional subjects of praise. ${ }^{4}$ The Amant Vert remains unalterably determined by his

\footnotetext{
${ }^{2}$ Jean Lemaire de Belges, Les Epîtres de l'Amant Vert, ed. by Jean Frappier (Geneva: Droz, 1948), I.321-2; hereafter, $E A V$.

${ }^{3}$ See Annette H. Tomarken, The Smile of Truth: The French Satirical Eulogy and Its Antecedents (Princeton: Princeton University Press, 1990), pp. 199-201.

${ }^{4}$ See Rosalie L. Colie, Paradoxia Epidemica: The Renaissance Tradition of Paradox (Princeton: Princeton University Press, 1966).
} 
small body, however exalted his speech and character may be. For Lemaire's paradoxical parrot is doubly ambiguous: like Folly in Erasmus's Moriae Encomium (1511), the Amant Vert is both the comically eulogised subject and the consequently unstable narrator of two poems whose playfulness depends upon sustaining, rather than resolving, that ambiguity. To what extent, then, does the ambiguity of the parrot as subject destabilise his judgments as narrator or affect his conceptions of nobility and vileness? More largely, what place is there for consistent conceptions within the unstable and destabilising genre of the paradoxical encomium? Lastly, how valuable a contribution can serio-comic ambiguity reliably make to the study of concepts - and particularly of versatile and fluctuating concepts - such as the vile?

This article compares the Amant Vert's conceptions of the vile with those found in less paradoxical forms. Firstly, it explores the instability in the physical, bodily criteria that generally govern villainy, in the various senses implied by Maurice de La Porte's epithets, in sixteenth-century birds (and thus in the Amant Vert as Lemaire's subject). Next, it examines the ambiguous value of parrots as arbiters of the vile (and thus of the Amant Vert as Lemaire's narrator). It then compares these physical criteria, often conceived in social terms, with those, conceived in moral terms, that implicitly determine entry into heaven and hell in the Epitres de l'Amant Vert. Finally, it questions whether vileness and its determining factors are quite as fixed as the clear-cut bodily distinction between the parrot and the dog that eats him initially suggests, and asks whether the Amant Vert himself is quite as unstable as the paradoxical genre of Lemaire's serio-comic encomium implies.

\section{Vile and noble birds: utility, aesthetics and value}

The attribution of human values and concerns to animals is part of Lemaire's poems' charm: its inappropriateness comically highlights the predominantly moral and social criteria by which the vile is generally judged. Not all Renaissance categorisations of birds as vile or 
noble are quite so whimsical: while they may reflect these moral and social criteria, they are chiefly governed by more stable physical or bodily criteria that affect (although not always consistently) assessments of birds' usefulness, beauty and financial worth. For falconers, 'vilain' is thus a technical term, as Ingrid de Smet explains:

Les qualifications « ignoble » ou « vilain » $[\ldots]$ indiquent un oiseau de proie accoutumé à se nourrir de charognes et non de gibier vif et qui est donc inutilisable pour la chasse. ${ }^{5}$

Carrion-eating is a natural condition that precludes birds from hunting; their 'vileté' is, to use one of La Porte's epithets, 'inutile'. ${ }^{6}$ It also retains its connotations of social hierarchy: through contrast with the implicit nobility of the birds of prey used in falconry, reflecting the nobility of falconry itself, the villainy of carrion-eaters is also 'basse', 'vulgaire' and 'humble'. ${ }^{7}$ If the nobility of falconry applies equally to men and birds, so too do contrastingly vile practices. This is evident in Nicolas Rigault's description of the villainy of fowling:

neque ad rem accipitrariam pertinent, sed potius ad fraudulentum aucupium, quod illectas aviculas superfusis retibus solet includere, aut viscatis virgis intricare. Inglorium id quidem et vile, nec immerito Platonis legibus ut sordidum et illiberalis otii negotium interdictum. ${ }^{8}$

[This does not apply to falconry, but rather to duplicitous fowling, which typically decoys small birds and ensnares them in spread nets or traps them with limed twigs. This is indeed unworthy and vile, and not undeservedly was it banned by Plato in his Laws as the sordid business of an ungentlemanly pastime.]

\footnotetext{
${ }^{5}$ Ingrid A. R. De Smet, La Fauconnerie à la Renaissance: le 'Hieracosophion' (1582-1584) de Jacques Auguste de Thou (Geneva: Droz, 2013), p. 451.

${ }^{6}$ La Porte, p. 592.

${ }^{7}$ La Porte, p. 592. On the perception of falconry as noble, see De Smet, pp. 13-83; on François I's divine ability to tame wild animals, see Pierre Belon du Mans, L'Histoire de la nature des oyseaux, ed. by Philippe Glardon (Geneva: Droz, 1997), pp. 189-90.
}

${ }^{8}$ Nicolas Rigault, ‘Epistula N. Rigaltii ad Ludovicum Regem', in De Smet, p. 420. 
While birds of prey derive their nobility from association with the aristocracy of falconers, carrion-eaters are analogous to fowlers in their villainy: the social hierarchy of hunting applies with precise equivalence to men and birds.

Yet vileness in birds need not be useless, either within or beyond falconry. Pierre Belon, in his Histoire de la nature des oyseaux (1555), describes the protection offered in England, on pain of a large fine, to the raven, because it helps prevent infection by eating rotting corpses: its vile carrion-eating is not 'inutile' but rather 'sordide' or 'odieus', reflecting something approaching disgust. ${ }^{9}$ Furthermore, just as their utility protects ravens in England, so their vileness protects them elsewhere: humans seldom eat scavengers, and Belon specifies that the raven's carrion-eating acts as a vile guarantee against its being eaten although this does not extend to its young. ${ }^{10}$ The distinction between vile and noble birds not only reflects their own eating habits, but may also govern whether they are eaten themselves, although neither active nor passive involvement with eating is a stable indicator of villainy or nobility in birds.

Similarly, within falconry, villainy is not entirely stable, even in its technical sense. Jacques-Auguste de Thou, in his epic poem on falconry, the Hieracosophion (1582-84), uses the term both with its generally accepted designation and in a more specific context, as De Smet explains:

Le texte de De Thou [...] implique qu'un ignoble est surtout un oiseau moins beau de physique, mais qui sert tout de même à la chasse au vol. ${ }^{11}$

\footnotetext{
${ }^{9}$ Belon, p. 279; La Porte, p. 592.

${ }^{10}$ Belon, p. 279.

${ }^{11}$ De Smet, p. 467.
} 
Falconry here condemns a bird as 'ignoble' or a 'vilain' not because it is 'inutile' but because it is 'laid'. ${ }^{12}$ Thus, for De Thou, villainy has two discriminating functions: firstly, it excludes the carrion-eaters that are precluded from hunting; secondly, it distinguishes those hunting birds whose physical appearance - their smaller size and lesser beauty - rather than eating habits demeans them in the aristocratic hierarchy of falconry. A vile appearance lowers a bird's aesthetic and thereby social status, but it does not affect its utility.

This is because De Thou rejects the conventional correlation between appearance and character:

\footnotetext{
Nec parvo in pretio, aut vilis censetur apud nos, Degenerem ob formam, qui vulgo Ignobilis audit. Nam siquidem aut animis non est, aut viribus impar; Sed formae vitium ingenita virtute rependat, Optimus is, praedaeque insano fervet amore, Emissusque alios longe post terga relinquet. ${ }^{13}$
}

[The bird commonly called the Vilain is not considered these days to be vile or of lower price because of its unworthy appearance. For since a Vilain is not inferior in courage or in strength, but compensates for its defective appearance by its natural virtue, it is excellent, and burns with a furious desire for prey, and once set in flight, leaves the others far behind.]

The bird may be called 'Ignobilis' (Vilain in French) because of its physical appearance, but it is not 'vilis' in the sense of being ordinary or cheap: De Thou acknowledges this further meaning of vileness, even as he corrects it. Instead, the character of the birds that De Thou defends, while not determined by their appearance, may be positively influenced by it: he portrays the 'Ignobilis' as conscious of its physical or aesthetic inferiority, and so seeking to

\footnotetext{
${ }^{12}$ La Porte, p. 592.

${ }^{13}$ De Thou, Hieracosophion, in De Smet, p. 252.
} 
redeem the vileness of its body through the greatness of its soul. For De Thou, behaviour and character are more valuable than appearance as indicators of the vile.

Bodily appearance may nevertheless contribute indirectly to the nobility imputed to birds whose beauty or exoticism makes them exclusively expensive and thereby valuable as status symbols for their aristocratic owners. ${ }^{14}$ Their nobility derives partly from their opulent owners, whose expenditure distinguishes them from the 'vilain' as 'chiche' or 'avare', and partly from their own value, through contrast with 'vileté' as 'contemptible' and 'mesprisée'. ${ }^{15}$ Whereas the value of birds that are delicious or luxurious to eat derives precisely from their utility, birds whose expense derives from their exoticism or beauty are not generally eaten: their preservation relies on their aesthetic value rather than on any functional usefulness. Belon specifies that the kingfisher, kept as a plaything for children or else dried and preserved for its beauty, is the only river bird not to be eaten, any more than the parrot:

Les Papegaux servent seulement pour la beauté de leurs plumes, \& pour parler en cage. ${ }^{16}$ Jean de Léry's description of the reluctance with which, during his return from Brazil, he eventually ate a parrot destined for the Admiral de Coligny emphasises the extremity of the hunger that drove him, regretfully, to this last resort. ${ }^{17}$ Yet the very inedibility of such birds also denies them any legal value. Domestic pets have no legal status in the early modern world, making birds such as parrots expensive but worthless precisely because they are

\footnotetext{
${ }^{14}$ See Gustave Loisel, Histoire des ménagéries de l'Antiquité à nos jours, 3 vols (Paris: Doin \& Laurens, 1912), I, p. 238.

${ }^{15}$ La Porte, p. 592.

${ }^{16}$ Belon, p. 58; cf. p. 218.

${ }^{17}$ Jean de Léry, Histoire d'un voyage faict en la terre du Bresil 1578, ed. by Frank Lestringant (Paris: Livre de Poche, 2008), pp. 536-7; cf. pp. 526-7 and 530.
} 
useless: their only value is aesthetic. ${ }^{18}$ These shifting conceptions of avian value confirm the ambiguity of the Amant Vert's status, making him a properly paradoxical subject for Lemaire's praise.

\section{Paradoxical parrots: ambiguous arbiters}

One notable example of such paradoxical worthlessness and of the ambiguity of parrots as both subjects and narrators emerges from Conrad Gesner's well-known anecdote about Henry VIII's parrot, as related in his De Avium natura of 1555:

Nuper amicus quidam recitauit nobis iucundam de psittaco historiam: quem aiebat Londini in Anglia e palatio regis Henrici octaui in præterlabentem fluuium Thamesin decidisse, \& uoce consueta iis, qui quantocunque pretio (ut in periculo aliquo constituti, aut alii etiam ioco) portitorem ex opposita ripa vocant, a bott a bott for twentye pownd: quod est, Cymba cymba uel pro uiginti libris, quam sæpissime enunciari audiuerat, \& tum commodissime meminerat, exclamasse. Ea excitatum portitorem quendam, propere adnauigasse $\&$ sustulisse auem, \& regi (ad quem pertinere agnoscebat) reddidisse, tantum mercedis sperantem, quantum auis promiserat. Rex pactus est ut quam auis interrogata denuo mercedem dixisset, acciperet. Placuit. Respondit auis, Gibe the knabe a grott: id est, Da nebuloni solidum. ${ }^{19}$

[A friend recently told me a merry tale about a parrot, which he said fell from King Henry VIII's palace in London into the river Thames that flowed past. The parrot's voice had been trained by those who call to a boatman from the opposite bank offering a specific price (some because they are in danger, others in jest), and so it cried out 'a boat, a boat, for twenty pounds!', which it had very often heard said, and then most conveniently remembered. The boatman it summoned quickly rowed over, and rescued the bird, and returned it to the King (to whom he recognised that it belonged), hoping for the reward that the bird had promised.

\footnotetext{
${ }^{18}$ See Erica Fudge, Perceiving Animals: Humans and Beasts in Early Modern English Culture (Basingstoke: Macmillan, 2008), p. 133.

${ }^{19}$ Conrad Gesner, Historiae Animalium Liber III. qui est de Avium natura (Zurich: Christopherus Froschoverus, 1555), p. 693. Ulysse Aldrovandi repeats the anecdote to demonstrate the intelligence of the parrot: Ornithologiae hoc est de avibus historiae libri XII (Bologna: Giovanni Battista Bellagamba, 1599), XI.1, p. 649.
} 
The King offered him a deal whereby he would accept the price that the parrot, when asked again, stated. He agreed. The parrot replied, 'Give the knave a groat.']

Gesner's merry tale may celebrate the parrot's intelligent speech, but it does so at the expense of the boatman who trusts such speech, and who is doubly humiliated as a result: he is outwitted by a parrot and denied his reward. ${ }^{20}$ It extends the sixteenth-century debate over the value of speech in parrots, as a sign either of rational, articulated thought or of merely meaningless reiteration, to question whether a parrot can be trusted to speak truthfully or expected either to share or to reflect ethical concerns with veracity. ${ }^{21}$ The obvious mimicry in the parrot's first speech ('a bott, a bott') disguises whether it speaks in seriousness (as 'tum commodissime meminerat' suggests) or in jest: he has models for both, and in either case, his mimicry is apposite. In contrast, the parrot's second speech ('Gibe the knabe a grott') is not ostensibly mimetic: it suggests an autonomous intelligence and loyalty to Henry VIII, saving him from paying the boatman more than his due. Nevertheless, in the grand hauteur of its lordly reply, the parrot implicitly parrots his royal master; Henry's orchestration of this 'trial by parrot' suggests he may have good reason to be confident of predicting the parrot's response. In context, this reply acquires a meaning (even if not one consciously intended by the parrot) that suits Henry's ends.

The ambiguity of the parrot's actions, questioning whether its rescue is actually necessary (in which case a groat, rather than twenty pounds, might be all the boatman's redundant services are worth), extends to its status and judgments. The parrot's triumph over the boatman it has tricked (either by pretending to be in danger, or by cheating him of his reward) is paradoxical: it devalues the boatman, but only by placing a price upon the parrot's

\footnotetext{
${ }^{20}$ See Bruce Thomas Boehrer, Parrot Culture (Philadelphia: University of Pennsylvania Press, 2004), pp. 80-81.

${ }^{21}$ See Terence Cave, Pré-histoires II: langues étrangères et troubles économiques au XVI siècle (Geneva: Droz, 2001), pp. 29-44.
} 
own head - a mere groat. Neither value nor venality distinguishes the parrot from the boatman who wishes to profit from his lucrative rescue just as the parrot (and implicitly, Henry) wishes to avoid unnecessary financial outlay. The boatman may be grasping, but he acts in good faith, whereas the parrot - loyally representing Henry, acting as an unreliable witness, cast as judge, and not, apparently, bound by the compact - does not: one or other of its two speeches has tricked the boatman, who is consequently cheated of his promised reward. Perhaps the moral of the story is not to take a parrot at its word.

In contrast to Henry VIII's parrot, Lemaire's Amant Vert has considerable narrative authority: nothing in the poems suggests he is anything other than reliable. His narrative judgments are nonetheless destabilised by his serio-comic status: the grandiloquence of his self-perception as noble, albeit confirmed by his fortunes in the afterlife, is at odds with his diminutive stature and with a literary tradition that makes it hard to grieve in all seriousness over his death. Lemaire's subject-matter and serio-comic tone both derive from Ovid's elegiac lament for Corinna's parrot, the humour of which lies precisely in the contrast between the gravity of the tone and the levity of its subject:

ossa tegit tumulus, tumulus pro corpore magnus, quo lapis exiguus par sibi carmen habet.

[His bones are enclosed in a tomb, a tomb of appropriate size for his body, and upon it a tiny stone bears an equally tiny inscription. $]^{22}$

The acknowledgement of the smallness of the parrot's body and therefore of its physical epitaph extends to its literary epitaph, in the form of Ovid's poem.

Lemaire, like Ovid, recognises the paradox of praising small subjects, and his parrot narrator acknowledges, in the opening lines of the poem, the humility of his 'povre corps

\footnotetext{
${ }^{22}$ Ovid, Amores, ed. and trans. by Joan Booth (Oxford: Aris \& Phillips, 1991), II.6, 11. 59-60, pp. $42-43$.
} 
tremblant' $(E A V$, I.4). The humility of this self-description, clearly intended to heighten the pathos of the Amant Vert's tragic fate, is, however, short-lived, as he quickly emphasises the contrast between his poor body and his noble soul:

Car, et comment pourroit ung cueur si gros,

En corpz si foible et si petit enclos,

Passer le jour que de moy te depars,

Sans se crever et pourfendre en deux pars? (EAV, I.13-16)

The Amant Vert resembles De Thou's Vilain in that his small body, described as 'foible', 'petit' and 'povre' to elicit pity for his fate, does not determine his nobly magnanimous character. Yet unlike De Thou's Vilain, the Amant Vert is small but also beautiful, and he consequently subscribes fully to the traditional association between bodily beauty and nobility of soul that De Thou rejects. This correlation is seen in his description of his courtly devotion to Marguerite:

Car, quand j'entendz le nom de ta personne,

Dont le record si doulx cymballe et sonne,

Je tressaulx tout de l'amoureux desir

Qui mon gent corpz fit en terre gesir. (EAV, II.11-14)

The Amant Vert's 'gent corpz' reflects his noble sentiments; it also echoes his earlier description of Marguerite:

J'ay veu tes parfaictes beautéz,

Et ton gent corpz, plus poly que fine ambre. (EAV, I.110-11)

This echo thus extends Marguerite's bodily nobility, corresponding to her noble rank and character, to apply, along with her perfect beauty, to the Amant Vert himself. Like Henry VIII's parrot, the Amant Vert parrots his royal owner; by focusing upon his beautiful appearance rather than his bodily size, he attempts to resolve his inherited Ovidian paradox while maintaining bodily criteria as a means of determining the noble and the vile. 


\section{Villainy and death: the Amant Vert's Underworld}

Just as the Amant Vert's noble character is reflected in his physical appearance, so is the dog's contrasting vileness:

Je voy ung chien, je voy ung viel mastin,

Qui ne mengea depuis hier au matin,

A qui on peut nombrer toutes les costes,

Tant est haÿ des bouchiers et des hostes. (EAV, I.311-4)

The lexical echoes that cement the association between the Amant Vert and the nobility epitomised by Marguerite also confirm the association between the dog and a new aspect of the vile: death. The description 'ung viel mastin' anticipates that of the Stygian boatman Charon as he escorts the parrot to the Underworld:

Or nous passa le viellart nautonnier

Qu'on dit Karon, tresvilain pautonnier. (EAV, II.85-6)

The association between the vile and the old extends to include death, portrayed as black and ugly: the Underworld is a 'valée obscure' ( $E A V$, II.78) in which 'la clarté fault' ( $E A V$, II.89), and it is guarded by another dog, Cerberus, 'le portier lait et noir' (EAV, II.75). Death thus comes to epitomise the vile.

Alongside epitomising the vile, death also confirms it. The parrot dictates that the vile dog need not be punished by Marguerite, as it will be condemned in the afterlife:

Mais souffira, sans plus, que tu mauldie

La ville beste, oultrageuse et hardie,

Qui mon gent corpz (du tien enamouré)

Aura ainsi deffaict et dessiré. ( $E A V$, I.345-8)

Death will become the ultimate arbiter between the vile and the noble, authorising the physical, bodily criteria informing the Amant Vert's judgments, but also introducing Christian criteria that equate the vile with sin, even though Lemaire's Underworld, occupied 
exclusively by animals, remains resolutely classical, as the fact that a suicide is permitted to enter paradise demonstrates. The parrot's ready adoption of Christian criteria indicates a desire less to parrot human morality than to ally it with natural avian concerns. ${ }^{23}$ Thus the vile eating habits that feature prominently amongst the damned, as might be expected in an avian Underworld, are condemned on moral grounds as gluttony, obscenity or murder. The dog that ate the Amant Vert is one of several murderous eaters, including the Minotaur, Actaeon's hounds and the snake that bit Eurydice: as killing birds becomes equated with killing humans, so murder, rather than eating habits, is condemned. ${ }^{24}$ Indeed, eating plays no part in the case of the vile pig that inadvertently killed Louis VI's son, the dauphin Philippe, in 1131:

Et ce porc vil, qui trop s'esvertua,

Près de Paris le filz du roy tua. (EAV, II.173-4)

The pig startled the dauphin's horse, prompting the accident that killed him, but is condemned as if directly responsible for his death: 's'esvertuer' has no virtue in a creature that is 'vil'.

Similarly, the villainy of carrion-eating, which for De Thou lies in its uselessness in falconry, is judged on moral grounds. ${ }^{25}$ One of the condemned birds is Noah's raven:

Ce noir oiseau, de tous desavoué,

Est le corbeau de l'arche de Noé:

\footnotetext{
${ }^{23}$ See Hélène Naïs, Les animaux dans la poésie française de la Renaissance (Paris: Didier, 1961), p. 438.

${ }^{24} E A V$, II. 138-82.

${ }^{25}$ The bestiary tradition associates carrion-eating (in the ibis and the kite) with uncleanness, sloth, and vile habitats: see Florence McCulloch, Mediaeval Latin and French Bestiaries (Chapel Hill: University of North Carolina Press, 1962), pp. 132-5.
} 
Encor siet il sur sa caroigne ville. ${ }^{26}(E A V$, II.135-7)

The condemnation combines disgust for the raven's fondness for vile carrion with moral objection to its unhelpful disobedience to Noah: having been sent to see if the flood-waters had receded, it failed to return to the Ark. ${ }^{27}$ In contrast, the Amant Vert will find the Elysian Fields populated by creatures virtuously associated with the holy family or with specific saints (EAV, II.456-93).

The carrion-eating epitomised by this particular raven anticipates a generic condemnation of ravens amongst other sinful birds:

Corbeaux vilains, piës injurïeuses,

Cailles, perdriz pervertissans nature. ${ }^{28}(E A V$, II.210-11)

The notorious lust of the partridge, leading it to sodomy, derives from Aristotle and Pliny: Pierre Belon and Charles Estienne both follow Aristotle's claim that partridges and quails are so salacious that when the females are laying, the males will fight and the loser behave like the victor's female, even sexually. ${ }^{29}$ Pliny's description of the female partridge as so lustful

\footnotetext{
${ }^{26}$ Brunetto Latini, Li Livres dou Tresor, ed. by Spurgeon Baldwin and Paul Barrette (Tempe, Arizona: Arizona Center for Medieval and Renaissance Studies, 2003), suggests two reasons for the raven's failure to return: 'ou por ce que trove charoignes, ou por ce qu'i moruit es eiues parfondes' (I.157, pp. 125-6).

${ }^{27}$ Genesis 8:7. There is no biblical explanation for the raven's failure to return, nor any reference to carrion-eating or colour transformation, although the raven's colour and attitude are implicitly contrasted with those of Noah's eirenic dove.

${ }^{28}$ The villainy of ravens may also reflect their traditional association with ill augury (conforming to the Latin sense of obscenae aves), reflected in Lemaire's Le Temple d'Honneur et de Vertus, ed. by Henri Hornik (Geneva: Droz, 1957), p. 66, 1. 454.

${ }^{29}$ Belon, p. 257; Charles Estienne, L'Agriculture et Maison Rustique (Paris: Du Puy, 1570), fol. 34v; cf. Aristotle, Historia Animalium VIII(IX).VIII.613b6-614a8; Pliny, Naturalis Historia, X.LI.100-102. Jean Frappier $(E A V$, p. 59$)$ identifies Brunetto Latini as the source for Lemaire's perverted partridges: see Latini, I.167, pp. 130-31.
} 
that she can be impregnated by wind alone survives in the bestiary tradition; Belon follows both Aristotle and Pliny in describing the abundance of sterile eggs conceived amongst themselves by female pigeons. ${ }^{30}$ Avian homosexuality is not confined either to partridges and quails, or to male birds.

Vile eating habits continue to inform the Amant Vert's list of creatures that have been generically damned, including:

Pourceaux gourmans et grives grandz yvresses,

Voultours tresordz et huppes sepulchrales. (EAV, II.218-9)

The condemnation of porcine gluttony and avian drunkenness, with its obvious Christian overtones, introduces other obscene eating habits implicit in the vile dirtiness ('ord' is one of La Porte's epithets for 'vilain') denounced in the following line. ${ }^{31}$ The adjective 'tresordz', applied to vultures, suggests carrion-eating, while the hoopoe both lives by tombs and feeds on dung, prompting Pliny to describe it as an 'obscena [...] pastu avis.' 32 Yet the hoopoe is not exclusively condemned, nor is it unambiguously vile. Aelian explains that its use of human excrement, not as food but for building its nest, is governed by practical considerations, intended to disgust and deter its human predators; he also praises its virtuous qualities, honouring its parents by tending to them in old age. ${ }^{33}$ The ambiguity of the hoopoe - combining vile scatophagy with Christian exemplarity - mirrors the ambiguity with which

\footnotetext{
${ }^{30}$ McCulloch, p. 152; Belon, p. 315; Aristotle VI.II.561a1-2; Pliny X.LXXX.166.

${ }^{31}$ La Porte, p. 592.

32 Pliny X.XLIV.86; cf. Isidore of Seville, Etymologies XII.7.66. For examples of the consequent Christian condemnation of the hoopoe as diabolical, see McCulloch, pp. 126-7; Paul Sébillot, Le folklore de France: la faune (Paris: Imago, 1984), p. 184.

${ }^{33}$ Aelian, On the Characteristics of Animals, III.26 and XVI.5. Guillaume le Clerc's description of the hoopoe as dirty but morally honourable reconciles both aspects: see McCulloch, pp. 126-7.
} 
vileness is judged in Lemaire's Underworld, as vile eating habits are codemned through a combination of natural and moral concerns.

The moral condemnation of such damnably greedy creatures implicitly attributes virtuous innocence to a contrastingly minimal appetite. Ovid light-heartedly emphasises the sobriety and temperance of Corinna's parrot, although he attributes this to its unbridled loquaciousness, preventing it from eating, rather than to any virtuous restraint. ${ }^{34}$ His emphasis on sobriety comically counters the notorious classical association between parrots and drunkenness: Aristotle and Pliny both state that parrots become more outrageously loquacious (or salacious) when under the influence of alcohol. ${ }^{35}$ In contrast, it is a spiritual intoxication that is finally accorded to Lemaire's chaste and very sober parrot:

Illec fuz je par Mercure sommé

De boire ung trait de l'eaue oblivieuse,

Qui perdre fait toute amour envïeuse

De vouloir restre ou monde temporel

Pour le plaisir et deduit corporel;

Si en buz tant que presque je fuz yvre,

Et des adoncq n'euz vouloir de revivre. (EAV, II.268-74)

The effusive narration of the Amant Vert's second letter perhaps suggests that his spiritual intoxication by the waters of Lethe has indeed made him loquacious and even borders on a form of poetic ecstasy.

\section{The stability of bodily markers of the vile}

The Amant Vert's faith in the correlation between appearance and character is confirmed and rewarded when the parrot enters paradise: Minos judges the Amant Vert's immaculate beauty to be a perfect reflection of his virginal, unsullied life ( $E A V$, II.255-64). If vileness, associated

\footnotetext{
${ }^{34}$ Ovid, Amores II.6, 11. 29-32, pp. 42-43.

${ }^{35}$ Aristotle VII(VIII).XII.597b27; Pliny X.LVIII.117.
} 
with the old, the black and the ugly, and so with the attributes and causes of death, is condemned, then the contrasting nobility of the parrot's beautifully green body, associated with exuberant life, confirms his place in paradise. Yet it is precisely this contrast with death that has led him to his death. As Mary McKinley has demonstrated, the Amant Vert's suicide is triggered by his despair over his inability to transcend his alterity: in a period of black mourning, following the death in 1504 of Marguerite's husband, Philibert de Savoie, he remains irrepressibly green and chirpy, just as he remains unavoidably a parrot, not a human, at Marguerite's court. ${ }^{36}$ The Amant Vert's inability to adapt his inappropriate beauty leads this parrot to cease to be a parrot, since he is unable to parrot in the face of grief. The impossibility of the metamorphosis he desires demonstrates his bodily stability and, consequently, his unswerving character, both predetermined by and reflected in his appearance, and judged accordingly by Minos.

Seldom, however, is either character or appearance quite as stable as the Amant Vert suggests. For De Thou, vileness is labile in hunting birds, whose character (not governed by appearance) is liable to change:

Acceptam is siquidem feret ægra mente repulsam, Conscius et probri aut vacuas secedet in auras, Æternum aut mœrens ignavos exiget annos. ${ }^{37}$

[Indeed, if a bird takes a defeat it has suffered badly, and is conscious of its disgrace, either it will fly off on the empty breeze or, forever grieving, it will spend years as a Vilain.]

\footnotetext{
${ }^{36}$ Mary McKinley, 'Parrots and Poets: Writing Alterities in Scève and Lemaire de Belges', in Self and Other in Sixteenth-Century France, ed. by Kathryn Banks and Phillip Ford (Cambridge: Cambridge French Colloquia, 2004), pp. 1-14. McKinley argues that the parrot's desired transformation into a suitably black-clad crow is subsequently provided by Scève in Délie 247: Maurice Scève, Délie, ed. by I. D. McFarlane (Cambridge: Cambridge University Press, 1966), p. 253.

${ }^{37}$ De Thou, Hieracosophion, in De Smet, p. 312.
} 
Vile uselessness in hunting need not be a hereditary attribute, predetermined by nature or appearance; it may be acquired through a chance turn of events, although there is no indication that, once acquired, it will ever be lost. Vileness may thus be a consequence of a character trait: the proud refusal to accept shameful defeat and the lack of generosity towards a victor conform to La Porte's descriptions of the 'vilain' as 'superbe' or 'avare'. ${ }^{38}$

In contrast, the Amant Vert finds that his character, bound by his body, cannot change, even though there are precedents for the bodily metamorphosis he desires. French folk-lore and classical mythology provide examples of birds such as crows, ravens and blackbirds metamorphosed by divine punishment from white to black. ${ }^{39}$ Christian moralisations tend to attribute such metamorphoses to a profoundly altered emotional state: thus Estienne Forcadel, in his 'Encomie du Corbeau' (1551), ascribes the raven's colourchange to the grief of the raven that failed to return to the Ark, transformed by its pity for so many corpses and by regret over its separation from Noah. ${ }^{40}$ Similarly, French folk-lore perceives the rouge-gorge's red breast, representing Christ's blood, as testimony to its piety in pulling out the crown of thorns; the contrasting lack of compassion in the screech-owl and the magpie is reflected in their ugliness. ${ }^{41}$

Colour transformations triggered by profound and noble emotions, such as pity and grief, represent more fanciful variations of De Thou's Vilain, whose character and habits (but not appearance) are radically changed by an emotional state. Similarly physical (and psychological) metamorphoses are made available to other creatures in Lemaire's works: the

\footnotetext{
${ }^{38}$ La Porte, p. 592.

${ }^{39}$ Sébillot, p. 172; cf. e.g. Ovid, Metamorphoses, II.531-632, and Fasti II.243-66.

${ }^{40}$ See Etienne Forcadel, Euvres poétiques, ed. by Françoise Joukovsky (Geneva: Droz, 1977), pp. 250-3; see also Estienne Forcadel, Aviarium iuris civilis (Lyons: Jean de Tournes and Guillaume Gazeau, 1550), pp. 16-8.

${ }^{41}$ Sébillot, p. 171.
} 
swan and the dove seem to the grief-stricken narrator to turn their feathers black in the Regrets de la Dame Infortunée, on the death of Marguerite d'Autriche's brother, Philippe le Beau, in 1506, just as the flock of sheep do on the death of Pan (representing Pierre de Bourbon, who died in 1503) in the Temple d'Honneur:

La noire nue avoit de tous costez

Çaint le pourpris et tainct de sa couleur

Brebis, aigneaulx, pasteurs desconfortez.

Tous les troupeaulx en signe de douleur,

En obscur noir changerent toisons blanches

Et les bergiers prindrent dueil et pasleur. ${ }^{42}$

This change in colour is, initially, externally imposed by the cloud, either as a form of supernatural intervention or as the natural visual alteration in the sheep's and shepherds' appearance as the sunlight is obscured; it is then portrayed as if willed autonomously by the sheep, who change their colour as simply as the shepherds change their clothes. No such power of metamorphosis is granted to the Amant Vert.

Colour change in Renaissance animals is not typically ascribed to emotional states. ${ }^{43}$ Montaigne, in 'De la force de l'imagination', implicitly attributes the colour change in creatures such as the arctic hare to an imagination affected by sight rather than by emotion, although he also refers, as if to a commonly recognised example, to dogs that die of grief on their masters' death; his chapter concludes with the qualification that the veracity of his

\footnotetext{
${ }^{42}$ Lemaire, Le Temple d'Honneur, p. 70, 11. 556-561; cf. 'Les Regretz de la Dame infortunée' in Lemaire, Euvres, ed. by J. Stecher, 4 vols (Geneva: Slatkine reprints, 1969), III, p. 191; see also Naïs, pp. 415-7, who acknowledges the charm of the human psychology Lemaire lends to his grieving animals but specifies that such colour transformations are an 'absurdité' if taken literally (p. 416). ${ }^{43}$ The colour transformations of the chameleon, autonomously willed according to Aelian, II.14, are automatically affected by tangible contact (with anything other than red or white) according to Latini, I.85, pp. 141-2.
} 
examples is neither his responsibility nor his primary concern. ${ }^{44}$ The question of whether birds can alter their colours and, correspondingly, their behaviour raises the question of redemption: most of these colour transformations are unique and irrevocable. The Amant Vert, unwavering in body as in character, cannot fail to join the blessed; Minos's judgment, once made, will not be reversed.

\section{Coda: changing conceptions of vile birds}

The bodily consistency of the Amant Vert's humble size, undercutting his nobly exalted character, is essential to the paradox of Lemaire's poems. It is matched by a consistency in the Amant Vert's correlations between physical appearance, character and behaviour, suggesting a relatively stable definition of the vile, sustained through webs of association and ultimately determined by damnation in the afterlife. This adoption of moral criteria in the Underworld reflects the parrot narrator's equation of himself with humans: he describes himself as 'fort approchant la nature des hommes' (EAV, I.168), and his intermediary status as a parrot that parrots humans but remains a parrot permits his slippage between natural or avian and moral or human conceptions of the vile. That conception remains stable, however, even if the grounds for it shift, just as the parrot's beauty remains a stable indicator of the noble character for which he will be rewarded in the afterlife. If the Amant Vert is 'une noble pasture' at the point of his death, this is because of the agency that distinguishes him from vile carrion: he is alive, resembling prey rather than carrion, as he is eaten; his green liveliness dissociates him from vile mourning and death; finally, his noble soul is apparent in his determination to die as a martyr to love.

\footnotetext{
${ }^{44}$ Michel de Montaigne, Les Essais, ed. by Pierre Villey and V.-L. Saulnier (Paris: Presses Universitaires de France, 2004), I.21, pp. 104-6.
} 
For De Thou, writing a didactic epic on falconry, vileness is not fixed: the same term that describes unchanging characteristics such as physical appearance or eating habits also applies to a character that is liable to change. This introduction of fluctuation into the conception of vileness represents a considerable development from Lemaire's perception of the vile as determined by reprehensibility, reflected in a stable appearance, and confirmed in the afterlife. Villainy undergoes a further revision by the time of Casparus Dornavius, for whom all birds - precisely because they are not reprehensible - are vile. Dornavius's Amphitheatrum sapientiae socraticae joco-seriae (1619), an anthology of encomia either originally paradoxical in intention or else rendered paradoxical by virtue of their inclusion, contrasts the vile of the first of its two sections, pro vilibus, with the reprehensible of the second, pro damnosis. ${ }^{45}$ The encomia in pro vilibus eulogise subjects not usually significant enough to merit such praise: they are largely drawn from the natural world and include a wide selection of birds. ${ }^{46}$ Despite the appearance in this category of entries on the grubbier side of digestion (such as rumbling stomachs, lavatories and excrement), there is no sense of moral reprehensibility in Dornavius's conception of the vile, which is simply inconsequential - as befits an aesthetically appealing, chattily entertaining and innocuous but also, in practical terms, useless parrot. In contrast, the subjects of paradoxical encomia in pro damnosis suggest that the morally reprehensible is defined largely as that which is harmful to man: characters such as Helen of Troy, Bacchus and Nero are accompanied by abstractions such as war, drunkenness (and gout) and injustice, as well as by natural states such as blindness,

\footnotetext{
${ }^{45}$ Casparus Dornavius, Amphitheatrum sapientiae socraticae joco-seriae (Hanover: Wechel, 1619); see Tomarken, pp. 49-52.

${ }^{46}$ The anthology includes Ovid's elegy for Corinna's parrot and Aldrovandi's re-telling of Gesner's anecdote about Henry VIII's parrot: Dornavius, pp. 367-9.
} 
winter and old age. ${ }^{47}$ Unlike the inconsequential vile, the reprehensible all have concrete and highly pernicious effects.

The vile is both varied and versatile: its fortunes shift away from the reprehensibility that governs it for the Amant Vert, via the more physical and labile conceptions of De Thou, towards something more natural and pleasing in Dornavius. The inclusion of parrots amongst the inconsequentially vile subjects of encomia in Dornavius's anthology nevertheless confirms that the paradoxical status of Lemaire's Amant Vert persists. How valuably or consistently, then, do Lemaire's serio-comic and paradoxical poems contribute to definitions of the vile? Concurrence with the Amant Vert's self-perception as noble may depend upon paradox, but the grounds according to which the parrot determines villainy and nobility do not.

\footnotetext{
${ }^{47}$ On these categorisations, see Tomarken, pp. 3-27.
} 